\title{
Efficacy and Safety of Piperacillin-Tazobactam: Systematic Review and Metaanalysis
}

\section{Rosanova Maria Teresa ${ }^{1 *}$, Bes David ${ }^{2}$, Sberna Norma ${ }^{3}$, Herrera Ramos Estefanía $^{4}$ and Lede Roberto ${ }^{5}$}

${ }^{1}$ Infectious Diseases Chief of Clinical Practice Hospital Juan P. Garrahan, Buenos Aires-Argentina ${ }^{2}$ Internal Medicine Hospital Juan P. Garrahan, Buenos Aires-Argentina

${ }^{3}$ Pharmacy Chief Hospital Juan P. Garrahan, Buenos Aires Argentina

${ }^{4}$ Information Specialist Fundación Canaria de Investigación Sanitaria (FUNCANIS), Spain

${ }^{5}$ School of Medicine Universidad Abierta Interamericana, Buenos Aires, Argentina

\section{Review Article}

Volume 5 Issue 1

Received Date: January 21, 2021

Published Date: February 23, 2021

DOI: $10.23880 /$ jidtm-16000146

*Corresponding author: Dra Rosanova María Teresa MD PhD. Infectious Diseases Chief of Clinical Practice, Hospital Juan P. Garrahan Buenos Aires-Argentina, Email: margris2@yahoo.com.ar

\section{Abstract}

Introduction: Piperacillin-tazobactam (PTZ), although contested, is frequently utilized for empirical treatment of Gramnegative bacteria treatment.

Objective: Systematic review to evaluate if PTZ is associated with lower rates of treatment failure and less adverse effects than other comparators.

Material and Methods: Literature search in Embase, and MEDLINE databases using "piperacillin tazobactam" as leading term. A study qualified, when a properly randomized control trial (RCT) compared the efficacy and safety of PTZ with other antibacterial agents in an "intention to treat analysis" of clinically evaluable patients.

Results: Eleven studies fulfilled inclusion criteria. Pooled RR of failure risk rate was 25\% less using PTZ than other comparators (0.75; CI 95\% 0.59-0.95). Adverse effects were similar.

Conclusions: PTZ can be adequately considered for empirical treatment of patients with Gram-negative bacteria infections

Keywords: Piperacillin-Tazobactan; Efficacy; Bacterial Infections; Safety; Gram Negative; Empiric Therapy; Systematic Review; Failure

\section{Introduction}

Piperacillin-tazobactam (PTZ) is one of the most frequently utilized antibiotic agents for empirical Gramnegative bacteria coverage and remains active against a large proportion of extended-spectrum-beta-lactamase-producing Gram-negative bacteria [1] (ESBL-GN.) The efficacy of PTZ, its similar safety profile and the possibility of its use as monotherapy decreasing the need for combined antibiotic treatments, make the drug an attractive option in clinical practice $[1,2]$.
Carbapenems have been considered the most effective therapy for serious infections caused by resistant Gram negative bacteria; however, increased use has selection pressure for carbapenem resistance, an emerging threat which has contributed to increased selective pressure of multi-resistant Enterobacteriaceae [2-5]. To counterbalance this, PTZ is proposed as a carbapenem-sparing agent to reduce the incidence of multidrug-resistant bacteria and super infections [2]. 
With all these previous considerations, physicians have to prescribe the most appropriate empirical antibiotic therapy for Gram-negative infections.

To clarify this, we carried out a systematic review (SR) to evaluate if PTZ is associated with a lower rate of treatment failure compared with other antibiotics.

\section{Material and Methods}

\section{Search Strategies}

A literature search was carried out in Embase and
MEDLINE databases using the search terms "piperacillin tazobactan" with the following filters: Clinical Trial, Review, Comparative Study, Systematic Reviews, Randomized Controlled Trial (RCT), Controlled Clinical Trial, Practice Guideline, Meta-Analysis and Guidelines, and Use in Human Studies. The International Clinical Trials Registry Platform (WHO) and The Cochrane Library were also searched. Articles published in English, Spanish, or French till September 2019 was reviewed and articles reference lists were manually searched for additional relevant studies. See Table 1 Search strategy results.

\begin{tabular}{|c|c|c|c|c|}
\hline \multirow{2}{*}{ Database } & \multirow{2}{*}{ Access platform } & \multirow{2}{*}{ Inicial date } & \multirow{2}{*}{ Access date } & \multirow{2}{*}{$\begin{array}{c}\text { Results } \\
\text { Total }\end{array}$} \\
\hline & & & & \\
\hline MEDLINE & Ovid SP & 1946 & $30 / 09 / 2019$ & 957 \\
\hline EMBASE & Elsevier & 1974 & $30 / 09 / 2019$ & 1133 \\
\hline COCHRANE LIBRARY & Clarivate Analytics & 1995 & $30 / 09 / 2019$ & 142 \\
\hline TOTAL & & & & 2232 \\
\hline \multicolumn{4}{|c|}{ DUPLICATED } & 607 \\
\hline \multicolumn{4}{|c|}{ TOTAL } & 1625 \\
\hline \multicolumn{4}{|c|}{ International Clinical Trials Registry Platform (WHO) } & 32 \\
\hline
\end{tabular}

Table 1: Search strategy results.

The efficacy endpoint that was analyzed was treatment failure, which was defined as the inverse of trials' endpoints "success" according clinical evolution (CE). Safety end-point was the presence of any adverse effects (AE).

\section{Study Selection}

Data extraction and qualitative assessment were performed independently by two reviewers (MTR and DB). In case of disagreement, a third reviewer (RL) analyzed the data and managed the scientific discussion until consensus was reached.

Studies qualified if RCT assigned testing interventions by randomization procedures (non violable) with proper allocation concealment (non predictable); assessed the efficacy and safety of PTZ versus other antibacterial agent in an "intention to treat analyses" of clinically evaluable patients and had a loss-to-follow-up rate $\leq 15 \%$. Trials were included regardless their blinded or open-label design. Only trials in which the research unit were patients were considered.

\section{Data Analysis and Statistical Methods}

Efficacy end points were based on clinical evaluable (CE) populations of each study. Pooled risk ratio (RR) and 95\% confidence intervals (CIs) were calculated for treatment failure and safety outcomes using the random-effects model (Der-Simmonian-Laird) for more conservative analysis irrespective heterogeneity results. Calculations were carried out using the Metaanalysis calculator by EPIDATA software (WHO) ver. 3.1. Heterogeneity bias was estimated according to the Q-test and $I^{2}$ index. Publication bias was estimated by the Egger's test. A subgroup analysis was performed to assess bias associated to double blind or open label RCT related bias using J Primo, Sagunto Hospital, Spain software, applying the Mantel-Haenszel procedure. In any stage, the null hypothesis was rejected if $\mathrm{p}<0.05$. This study complies with the suggestions of the Preferred Reporting Items for Systematic Reviews and Meta-Analyses (PRISMA) statement [6].

\section{Results}

Literature search identified a total of 2264 related papers of which only 11 fulfilled inclusion criteria; and thus, were included in the SR. Figure 1 shows the results of the articles' selection process and Table 2 summarizes the main characteristics of the included articles. 
Journal of Infectious Diseases \& Travel Medicine

\begin{tabular}{|c|c|c|c|c|c|}
\hline Author & \multirow{2}{*}{ Indication } & \multicolumn{2}{|c|}{ Intervention } & \multirow{2}{*}{ Failure / Total } & \multirow{2}{*}{ AE / Total } \\
\hline year & & exper & control & & \\
\hline Eklund, 1993 & $\begin{array}{l}\text { Intra-abdominal } \\
\text { infections }\end{array}$ & pip-taz & $\begin{array}{l}\text { impipinem / } \\
\text { cilastin }\end{array}$ & $\begin{array}{c}\text { Exper:: } 4 \text { / } 55 \text { Control: } \\
18 \text { / } 58\end{array}$ & $\begin{array}{l}\text { Exper:: } 13 \text { / } 55 \\
\text { Control: } 14 \text { / } 58\end{array}$ \\
\hline Marra, 1997 & $\begin{array}{l}\text { Serious bacterial } \\
\text { infections }\end{array}$ & pip-taz & imipinem & $\begin{array}{c}\text { Exper: } 24 \text { / } 75 \text { Control: } \\
23 \text { / } 75\end{array}$ & $\begin{array}{c}\text { Exper: } 4 \text { / } 75 \\
\text { Control: } 12 \text { / } 75\end{array}$ \\
\hline Jaccard, 1998 & $\begin{array}{l}\text { Nosocomial neumonía } \\
\text { or peritonitis }\end{array}$ & pip-taz & $\begin{array}{l}\text { imipinem / } \\
\text { cilastatin }\end{array}$ & $\begin{array}{c}\text { Exper: } 17 \text { / } 151 \\
\text { Control: } 29 \text { / } 162\end{array}$ & $\begin{array}{c}\text { Exper:: } 22 \text { / } 151 \\
\text { Control: } 24 \text { / } 162\end{array}$ \\
\hline Ohlin, 1999 & $\begin{array}{c}\text { Intra-abdominal } \\
\text { infections }\end{array}$ & pip-taz & $\begin{array}{l}\text { cefuroxime / } \\
\text { metronidazole }\end{array}$ & $\begin{array}{c}\text { Exper: } 37 \text { / } 140 \\
\text { Control: } 39 \text { / } 1298\end{array}$ & $\begin{array}{l}\text { Exper: } 13 \text { / } 105 \\
\text { Control: } 9 \text { / } 100\end{array}$ \\
\hline Alvarez, 2000 & Nosocomial Pneumonia & $\begin{array}{l}\text { pip-taz / } \\
\text { amikacin }\end{array}$ & $\begin{array}{l}\text { ceftazidime / } \\
\text { amikacin }\end{array}$ & $\begin{array}{c}\text { Exper: } 10 \text { / } 88 \text { Control: } \\
10 \text { / } 36 \\
\end{array}$ & $\begin{array}{l}\text { Exper: } 21 \text { / } 88 \\
\text { Control: } 5 \text { / } 36\end{array}$ \\
\hline Naber, 2002 & $\begin{array}{l}\text { Complicated urinary } \\
\text { tract infections }\end{array}$ & pip-taz & $\begin{array}{l}\text { Imipenem / } \\
\text { cilastatin }\end{array}$ & $\begin{array}{c}\text { Exper: 25/ } 147 \text { Control: } \\
31 / 152 \\
\end{array}$ & $\begin{array}{c}\text { Exper: } 20 \text { / } 147 \\
\text { Control: } 16 \text { / } 152 \\
\end{array}$ \\
\hline Roy, 2003 & Acute pelvic infection & pip-taz & etarpenem & $\begin{array}{l}\text { Exper: } 12 \text { / } 153 \\
\text { Control: } 8 \text { / } 163 \\
\end{array}$ & $\begin{array}{c}\text { Exper: } 43 \text { / } 192 \\
\text { Control: } 48 \text { / } 214 \\
\end{array}$ \\
\hline Erasmo, 2004 & $\begin{array}{l}\text { Intra-abdominal } \\
\text { infections }\end{array}$ & pip-taz & $\begin{array}{l}\text { impipinem / } \\
\text { cilastin }\end{array}$ & $\begin{array}{c}\text { Exper: } 3 \text { / } 111 \text { Control: } \\
3 \text { / } 103 \\
\end{array}$ & $\begin{array}{c}\text { Exper: } 16 / 111 \\
\text { Control: } 19 \text { / } 103 \\
\end{array}$ \\
\hline $\begin{array}{l}\text { Saltoglu, } \\
2010\end{array}$ & Diabetic foot infections & pip-taz & $\begin{array}{l}\text { imipenem / } \\
\text { cilastatin }\end{array}$ & $\begin{array}{c}\text { Exper: } 16 \text { / } 30 \text { Control: } \\
23 \text { / } 32\end{array}$ & $\begin{array}{c}\text { Exper: } 9 \text { / } 30 \\
\text { Control: } 3 \text { / } 32\end{array}$ \\
\hline Aamir, 2015 & Febrile neutropenia & pip-taz & cefepime & $\begin{array}{c}\text { Exper: } 5 \text { / } 20 \text { Control: } \\
4 \text { / } 20\end{array}$ & $\begin{array}{l}\text { Exper: } 5 \text { / } 20 \\
\text { Control: } 6 \text { / } 20\end{array}$ \\
\hline Zhang , 2016 & Diabetic foot infections & pip-taz & etarnepem & $\begin{array}{c}\text { Exper: } 6 \text { / } 224 \text { Control: } \\
14 \text { / } 219\end{array}$ & $\begin{array}{c}\text { Exper: } 1 \text { / } 275 \\
\text { Control: } 3 \text { / } 275\end{array}$ \\
\hline
\end{tabular}

Table 2: Treatment failures and Safety of PTZ vs comparator in included studies.

Exper: Pip-taz; Control: comparator.

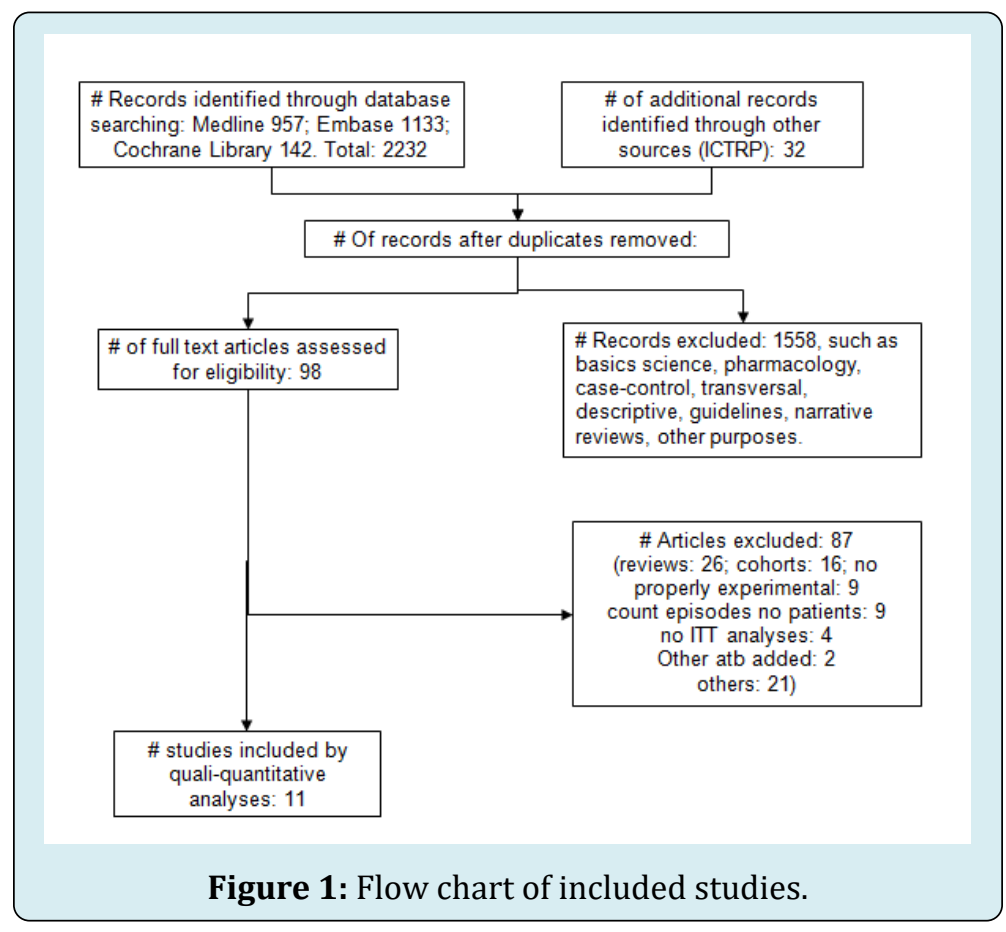


Only 4 trials out of 11 were double-blind [7-10]. The rest were open-label, single blind or no blindness. Two RCT included patients treated for diabetic foot infections $[8,11]$ four comprised patients with intra-abdominal infections [10,12-14] one focused on oncology patients with treated for febrile neutropenia [15] and four compared patients treated for other types of infections $[9,7,16,17]$.
The pooled incidence of treatment failure of the PTZ group was $13.32 \%$ and of the comparator group, $17.55 \%$. Table 3 shows the pooled RR (CI95\%) for the risk of failure, the effect size of each study and the results of the sensitivity analysis.

\begin{tabular}{|c|c|c|c|c|c|}
\hline Author & Year & $\mathbf{N}$ patients & $\mathbf{R R}$ & CI 95\% & Sensitivity analysis \\
\hline Eklund & 1993 & 113 & 0.23 & $0.08-0.64$ & 5.56 \\
\hline Marra & 1997 & 150 & 1.04 & $0.64-1.67$ & -5.02 \\
\hline Jaccard & 1998 & 313 & 0.62 & $0.36-1.09$ & 1.88 \\
\hline Ohlin & 1999 & 269 & 0.87 & $0.59-1.27$ & -3.53 \\
\hline Alvarez & 2000 & 124 & 0.4 & $0.18-0.89$ & 5.14 \\
\hline Naber & 2002 & 301 & 0.84 & $0.52-1.35$ & -2.46 \\
\hline Roy & 2003 & 316 & 1.59 & $0.67-3.80$ & -3.79 \\
\hline Erasmo & 2004 & 214 & 0.92 & $0.19-4.49$ & -0.85 \\
\hline Saltoglu & 2010 & 62 & 0.74 & $0.49-1.10$ & -0.89 \\
\hline Aamir & 2015 & 40 & 1.25 & $0.39-3.98$ & -2.18 \\
\hline Zhang & 2016 & 443 & 0.41 & $0.16-1.07$ & 3.51 \\
\hline \multicolumn{3}{|c|}{ Fixed effect model } & 0.77 & $0.65-0.92$ & \\
\hline \multicolumn{3}{|c|}{ Random effect model } & 0.75 & $0.59-0.95$ & \\
\hline
\end{tabular}

Table 3: Risk of treatment failure in individual studies and pooled results.

No relevant heterogeneity was detected (Q-test 14.93 ; DF 9; p 0.09. $I^{2} 35 \%$ ). Pooled RR failure risk rate was $25 \%$ less using PTZ than other comparators (0.75; CI 95\% 0.590.95) (Graphic 1).

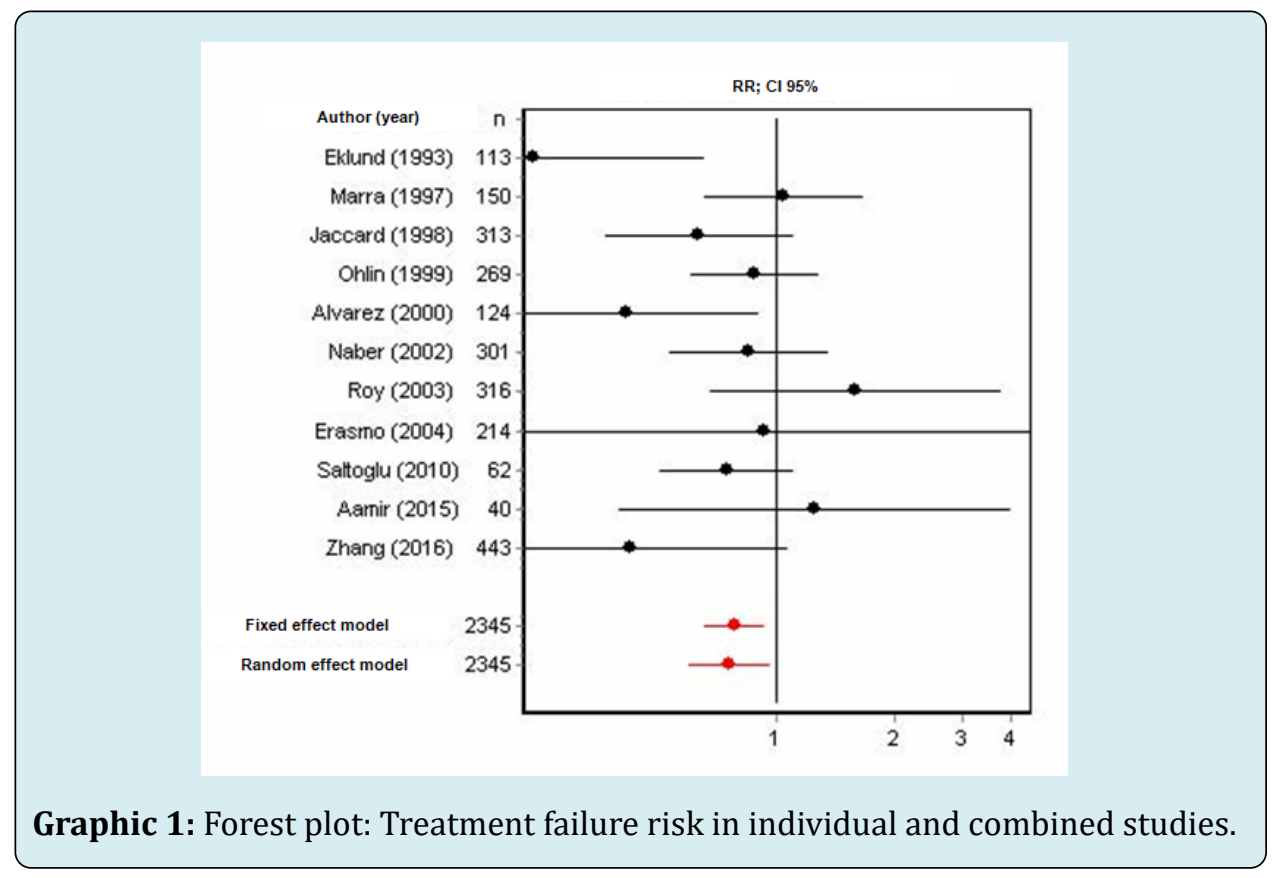


Cumulative metaanalysis (Graphic 2) illustrates that as the sample size increases, the effect size achieves more relevance and accuracy, showing a consistent trend toward less risk of treatment failure using PTZ.

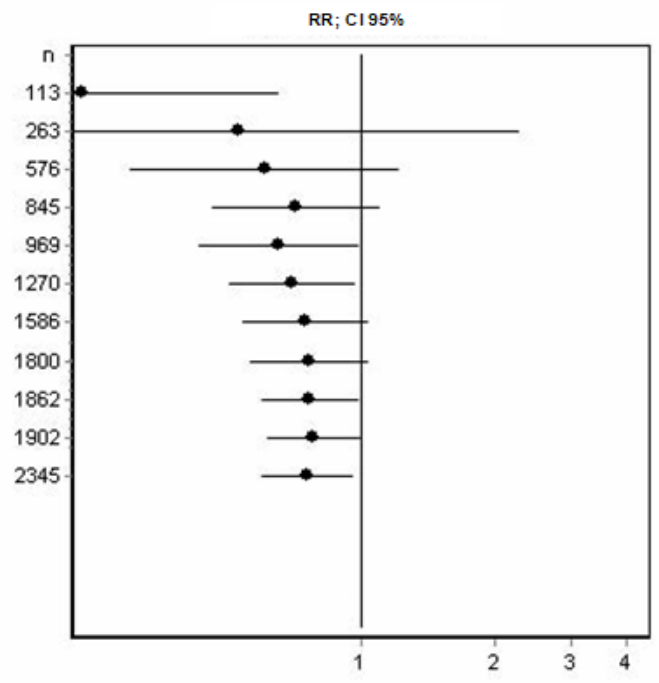

Graphic 2: Cummulative meta-analysis: Treatment failure rate.

The sensitivity analysis shows that [12] (5.56\%) is the most influential study and the least, [14] (-0.85\%). Both used the same comparator (imipinem-cilastin) and for the same indication (intraabdominal infections). The planned subgroup analyses according blindness, reveals that the pooled RR in double blind studies (n 1210 patients), is 0.91 ;
CI 95\% 0.61 to 1.35 , while that of the open label studies (n 1135), 0.67; CI 95\% 0.49 to 0.90 . The difference between them was not statistically significant, yielding a $p$ value of 0.23 (Z statistic 1.20). No risk of bias of publication was detected (Graphic 3).

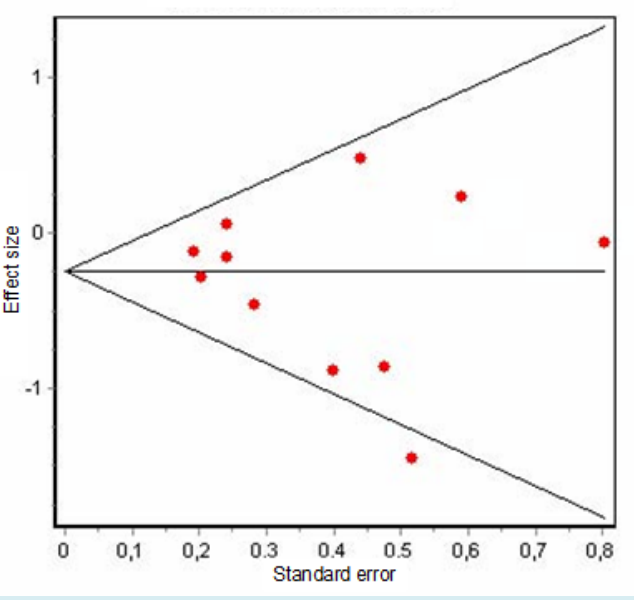

Graphic 3 Egger Test: Risk of bias publication.

Adverse events: Nor heterogeneity nor publication bias was detected in this comparison.

Treatment groups had similar rates of adverse events (15.75\% vs. 14.28\%) (Pooled RR 1.02; CI95\% 0.81-1.29).

\section{Discussion}

We conducted this SR to assess in children and adults, with all sorts of bacterial infections, the comparative 
effectiveness and safety of PTZ against available comparators.

Some authors state that PTZ is another treatment option to carbapenems, but limited to mild infections or urinary tract infections $[6,18,19]$.

This SR analyzed PTZ vs another antibiotic comparator in a wide type of infections, including intaabdominal infections, febrile neutropenia, infections in diabetic patients, nosocomial pneumonia, all of which cannot be considered minor clinical threats.

Our results suggest that PTZ leads to a lower rates of treatment failure and is well tolerated, consistent with the good safety profile of the beta-lactam class [1-5]. The cumulative metaanalysis showed a clear trend that the risk of treatment failure is lower for PTZ than for comparators, and that the incidence of adverse events was not different.

A strength of our study is that, to the best of our knowledge, this is the first systematic review and metanalysis on the efficacy and safety of PTZ that includes only properly randomized controlled trials minimizing selection bias. This means that given the precautions taken to minimize selection bias by including only properly RCT, the clinician, who must often prescribe antibiotic treatments before having the microbiological results, can be confident that the risk of failure with empirical PTZ is lower than if another antibiotic is indicated.

Concerns arose, when it was found that all RCT studies were conducted in a diversity of underlying diseases, with some antibiotic comparators that are not typically indicated in clinical practice for treatment of these pathologies, using different doses and follow-up periods, with some infections not being microbiologically documented or in absence of ESBL-GN, some studies with few participants and mostly having treated adults. However, no significant heterogeneity was identified in the study.

On the other hand, it is not possible to totally rule out that the obtained results are not linked to the bias protection grade of the adopted design.

Further studies are needed to better understand the role of PTZ in empiric treatment of patients in intensive care settings, with ESBL-GN microbiologically documented infections and particularly, in children.

\section{Conclusions}

PTZ can be considered an adequate antibiotic option for empirical treatment of serious infections due to gram negative bacterias.

\section{Summary points}

Piperacillin tazobactan (PTZ) is an antibiotic frequently used in medical practice for the treatment of Gram negative infections. The present SR suggests that PTZ has a lower risk of therapeutic failure than other antibiotics, while the safety profiles are the same.

\section{References}

1. CDC (2019) Antibiotic Resistance Threats in the United States, 2019. U.S. Department of Health and Human Services.

2. Chastain DB, White BP Cretella DA, Bland CM (2018) Is it time to rethink the notion of carbapenem-sparing therapy against extended-spectrum $\beta$-lact- amaseproducing Enterobacteriaceae bloodstream infections? A critical review. Ann Pharmacother 52(5): 484-492.

3. Tamma PD, Rodríguez Baño J (2017) The use of noncarbapenem $\beta$-lactams for the treatment of extended-spectrum $\beta$-lactamase infections. Clin Inf Dis 64(7): 972-980.

4. Bouxom H, Fournier D, Bouiller K, Hocquet D, Bertrand $X$ (2018) Which non-carbapenem antibiotics are active against extended-spectrum $\beta$-lactamase-producing Enterobacteriaceae Int J Antimicrob Agents 52(1): 100103.

5. Audrey N Schuetz, Sergio Reyes, Pranita D Tamma (2018) Point-Counterpoint: Piperacillin-Tazobactam Should Be Used To Treat Infections with Extended-Spectrum-BetaLactamase-Positive Organisms. J Clin Microbiol 56(3): e01917-17.

6. Moher D, Liberati A, Tetzlaff J, Altman DG and PRISMA Group (2009) Preferred reporting items for systematic reviews and meta-analyses: the PRISMA statement. PLoS Med 6(7): e1000097.

7. Naber K, Savov O, Salmen H (2002) Piperacillin 2g/ tazobactam $0.5 \mathrm{~g}$ is as effective as imipenem $0.5 \mathrm{~g} /$ cilastatin $0.5 \mathrm{~g}$ for the treatment of acute uncomplicated pyelonephritis and complicated urinary tract infections. Int J Antimicrob Agents 19(2): 95-103.

8. Zhang-Rong $\mathrm{X}$, Xing Wu R, Yang $\mathrm{X}$, Xiao Dong $\mathrm{Y}$, Guo Yue Yuan, et al. (2016) Ertapenem versus piperacillin/ tazobactam for diabetic foot infections in China: a Phase 3, multicentre, randomized, double-blind, activecontrolled, non-inferiority trial. J Antimicrob Chemother 71(6): 1688-1696.

9. Marra F, Reynolds R, Stiver G, Bryce E, K Sleigh, et al. 
(1998) Piperacillin/tazobactam versus imipenem: a double-blind, randomized formulary feasibility study at a major teaching hospital. Diagn Microbiol Infect Dis 31(2): 355-368.

10. Roy S, Igareda I, Angel Muller E, Ismail M, Hague C, et al. (2003) Ertapenem once a day versus piperacillintazobactam every 6 hours for treatment of acute pelvic infections: a prospective, multicenter, randomized, double-blind study. Infect Dis Obstet Gynecol 11(1): 2737.

11. Saltoglu N, Dalkiran A, Tetiker T, Bayram H, Tasova $Y$, et al. (2010) Piperacillin/tazobactam versus imipenem/cilastatin for severe diabetic foot infections: a prospective, randomized clinical trial in a university hospital. Clin Microbiol Infect 16(8): 1252-1257.

12. Eklund A, Nord CE (1993) A randomized multicenter trial of piperacillin-tazobactam versus imipenem/cilastatin in the treatment of severe intra-abdominal infections Swedish Study Group. J Antimicrob Chemother Suppl A: 79-85.

13. Ohlin B, Cederberg A, Forssell H, Solhaug JH, Tveit E (1999) Piperacillin/tazobactam compared with cefuroxime/metronidazole in the treatment of intraabdominal infections. Eur J Surg 165(9): 875-884.

14. Erasmo A, Crisostomo A, Yan L, Hong Y, Kuhn Uk Lee, et al. (2004)Randomized Comparison of Piperacillin/ Tazobactam Versus Imipenem/Cilastatin in the Treatment of Patients with Intra-abdominal Infection. Asian J Surg 27(3): 227-235.
15. Aamir M, Abrol P, Sharma D, Punia H (2016) A Clinical Evaluation of Efficacy and Safety of Cefepime Monotherapy Versus Piperacillin-Tazobactam in Patients of Paediatric Age Group With Febrile Neutropenia in a Tertiary Care Centre of north India. Trop Doct 46(3): 142-148.

16. Jaccard C, Troillet N, Harbarth S, Zanetti G, Aymon D, et al. (1998) Prospective Randomized Comparison of Imipenem-Cilastatin and Piperacillin-Tazobactam in Nosocomial Pneumonia or Peritonitis. Antimicrob Agents Chemother 42(11): 2966-2972.

17. Alvarez Lerma F, Insausti Ordenana J, Jorda Marcos R, Maravi Poma E, A Torres-Marti, et al. (2001) Efficay and tolerability of piperacillin/tazobactam versus ceftazidime in association with amikacin for treating nosocomial pneumonia in intensive care patients: a prospective randomized multicenter trail. Intensive Care Med 27(3): 493-502.

18. Harris PNA, Tambyah PA, Lye DC, Yin M, Tau H Lee, et al. (2018) Effect of piperacillin-tazobactam vs meropenem on 30-day mortality for patients with E coli or Klebsiella pneumonia bloodstream infection and ceftriaxone resistance: a randomized clinical trial. JAMA 320(10): 984-994.

19. Golan Y (2015) Empiric therapy for hospital-acquired, Gram-negative complicated intra-abdominal infection and complicated urinary tract infections: a systematic literature review of current and emerging treatment options. BMC Infect Dis 15: 313-320. 